\title{
Effect of temperature and dissolved oxygen on gravity sedimentation of the unicellular alga Dunaliella salina
}

\author{
Tomo-o Watsuji ${ }^{1,2}$, Angelica Naka $^{1 *} \mathbb{D}$, Yasuhiko Morita ${ }^{1}$ and Midori Kurahashi ${ }^{1}$
}

\begin{abstract}
Purpose: The microalgae Dunaliella salina is mainly cultivated as a source of natural $\beta$-carotene, but it can also be an important source of other nutrients such as protein, carbohydrate, and lipids. Harvesting and dewatering are considered the most expensive processes in the biomass production, so we proposed gravity sedimentation as a cost-effective method. The effect of temperature and dissolved oxygen concentration on the gravity sedimentation of normal cells and carotenoid-accumulating cells of Dunaliella salina was investigated in this study.

Methods: Dunaliella salina was cultivated in an f/2 culture medium at two different salinities, $12.5 \%$ (2.2 M NaCl) and $17.5 \%(3.3 \mathrm{M} \mathrm{NaCl})$. Carotenoid-accumulating cells were cultivated in a medium without a nitrogen source by removing $\mathrm{NaNO}_{3}$ from the $\mathrm{f} / 2$ medium and at two different salinities, $12.5 \%$ and $17.5 \%$. For gravity sedimentation tests, $10 \mathrm{~mL}$ of the suspended culture media were transferred to conical tubes and wrapped with aluminum foil for shading. The tubes were incubated at $4{ }^{\circ} \mathrm{C}, 10{ }^{\circ} \mathrm{C}, 15^{\circ} \mathrm{C}, 20^{\circ} \mathrm{C}, 25^{\circ} \mathrm{C}, 30^{\circ} \mathrm{C}, 35^{\circ} \mathrm{C}, 40{ }^{\circ} \mathrm{C}, 45^{\circ} \mathrm{C}$, and $50{ }^{\circ} \mathrm{C}$ for $4 \mathrm{~h}$ and $18 \mathrm{~h}$. For the gravity sedimentation under aerobic and anaerobic conditions, $10 \mathrm{~mL}$ of the suspended culture media were transferred to conical tubes and then purged with $20 \%$ oxygen and $80 \%$ nitrogen or $100 \%$ nitrogen for 10 min and wrapped with aluminum foil. The tubes were incubated at $25^{\circ} \mathrm{C}$ for $0.5 \mathrm{~h}, 1 \mathrm{~h}, 2 \mathrm{~h}$, and $3 \mathrm{~h}$.
\end{abstract}

Result: Recovery rates differed with temperature, salinity, and time. The recovery rate of normal cells and carotenoid-accumulating cells reached 79 to $96 \%$ at $20^{\circ} \mathrm{C}, 25^{\circ} \mathrm{C}$, and $30^{\circ} \mathrm{C}$ at $12.5 \%$ and $17.5 \%$ of salinity and after $4 \mathrm{~h}$. The recovery rate of both normal and carotenoid-accumulating cells in gravity sedimentation experiments was not significantly affected by changing initial dissolved oxygen in the cell-cultured media.

Conclusion: Considering that gravity sedimentation at the optimum growth temperature for $D$. salina presented high recovery rates, gravity sedimentation is expected to be a cost-effective method to harvest $D$. salina from open pond cultivation systems.

Keywords: Gravity sedimentation, Dunaliella salina, Temperature effect, Dissolved oxygen effect

\section{Background}

Microalgae are photosynthesizing microorganisms that use sunlight to produce carbohydrates, proteins, lipids, etc. (Ben-Amotz et al., 1985; Chew et al., 2017; Spolaore et al., 2006). Raw materials or products obtained from microalgae can be widely used in the production of food

\footnotetext{
* Correspondence: angelica.naka@mail.ecc.u-tokyo.ac.jp

${ }^{1}$ Graduate School of Agricultural and Life Sciences, The University of Tokyo,

1-1-1 Yayoi, Tokyo, Bunkyo-ku 113-0032, Japan

Full list of author information is available at the end of the article
}

and supplements, feed, medicine, fertilizers, cosmetics, and raw material for different industries such as the fermentation industry (Ariede et al., 2017; Chisti, 2018; Milledge, 2011). The advantage of using microalgae is that they grow around 10-50 times faster than terrestrial plants (Yen et al., 2013). We have paid attention to the unicellular green alga Dunaliella salina for the creation of an ecological and carbon-neutral society that does not release extra carbon dioxide, while able to conduct industry. D. salina possesses outstanding halotolerance

(c) The Author(s). 2021 Open Access This article is licensed under a Creative Commons Attribution 4.0 International License, which permits use, sharing, adaptation, distribution and reproduction in any medium or format, as long as you give

appropriate credit to the original author(s) and the source, provide a link to the Creative Commons licence, and indicate if changes were made. The images or other third party material in this article are included in the article's Creative Commons licence, unless indicated otherwise in a credit line to the material. If material is not included in the article's Creative Commons licence and your intended use is not permitted by statutory regulation or exceeds the permitted use, you will need to obtain permission directly from the copyright holder. To view a copy of this licence, visit http://creativecommons.org/licenses/by/4.0/. 
(up to $5 \mathrm{M} \mathrm{NaCl}$ ) and accumulates high amounts of $\beta$ carotene in the cell during the growth under salt, light, and nutrient stress conditions (Coesel et al., 2008a; Fisher et al., 1994; Pourkarimi et al., 2020). Tolerance of D. salina to extreme salt conditions makes it grow in hypersaline environments, reducing predators, especially the ciliate Fabrea salina and the brine shrimp Artemia salina (Elloumi et al., 2009; Post et al., 1983). Thus, as a source of valuable $\beta$-carotene, $D$. salina has been commercially cultivated at salt ponds in Israel, the USA, and Australia (Ben-Amotz, 1995; Borowitzka, 1997; Spolaore et al., 2006). Open-air cultures are preferred in largescale commercial algal cultures because of the higher cost for closed culture systems (Borowitzka, 1999). For instance, $D$. salina is cultured in large open-air ponds (up to 250 ha) without artificial mixing and bubbling in Australia. This represents an advantage because open-air cultures of the other main commercial microalgae such as Chlorella and Spirulina species require artificial mixing or additional energy input (Borowitzka, 1999). Therefore, it can be said that open-air culture systems of D. salina is economically viable.

This research aimed to establish a cost-effective technique for collecting $D$. salina as an inexpensive biomass. Methods available for harvesting or recovery of cultivated microalgae include centrifugation, flotation, filtration, flocculation, gravity sedimentation, electrophoresis techniques, and combined methods such as flocculation-sedimentation and flocculation-flotation (Chatsungnoen and Chisti, 2016; Junior et al., 2020; Milledge and Heaven, 2013; Okoro et al., 2019; Uduman et al., 2010). Since microalgal recovery by gravity sedimentation is an additive-free recovery method that utilizes gravitational force and enables reuse of culture medium, it has a clear advantage in terms of cost (Li et al., 2020; Najjar and Abu-Shamleh, 2020). However, this method is suitable for relatively large (ca. $>70 \mathrm{~mm}$ ) microalgae such as Spirulina (Velan and Saravanane, 2013). Thus, smaller-sized microalgal cells, including $D$. salina, lead to high cost in recovery from the culture medium (Grima et al., 2003; Mata et al., 2010; Verma et al., 2010). Given that the production of microalgae-derived products is a growing and promising market worldwide, low-cost raw materials and large production quantities are necessary. Thus, the applicability of gravity sedimentation as a cost-effective method for microalgal recovery should be considered, especially for large-scale production of biomass. Even though the settling velocity of Dunaliella cells in gravity sedimentation has been measured (Eppley et al., 1967), very limited research has been done on this harvesting method. Scientific articles published in the last few years include sedimentation as a harvesting method, but they neither show experimental results, nor propose any design for harvesting microalgae from mass culture. Also, the effect of temperature and dissolved oxygen on gravity sedimentation of $D$. salina has not yet been identified as far as we know. Thus, in this study, recovery rates of $D$. salina cells in gravity sedimentation were investigated at a wide range of temperatures, under aerobic and anaerobic conditions. Additionally, normal cells and carotenoid-accumulating cells of $D$. salina were used in the gravity sedimentation experiments.

\section{Results and discussion}

$D$. salina cultivated in the absence of nitrogen source accumulate $\beta$-carotene in their cells (Coesel et al., 2008b). When exposed to such nutrient stress, the cells change from ovoid to spherical in shape and from green to orange in color due to $\beta$-carotene accumulation (Ramos et al., 2011). In the present study, D. salina cultivated in the absence of nitrogen source at a salinity of $12.5 \%$ and $17.5 \%$ indicated such morphological and coloristic features. The carotenoid-accumulating cells cultured at $12.5 \%$ salinity were shown in Fig. 1a as a representative of the different salinities. On the other hand, D. salina cultivated in the presence of a nitrogen source at a salinity of $12.5 \%$ and $17.5 \%$ indicated normal morphological and coloristic features. The normal cells cultured at $17.5 \%$ salinity were shown in Fig. $1 \mathrm{~b}$ as a representative of the different salinities. The cell concentrations of $D$. salina cultured in the absence of nitrogen source at a salinity of $12.5 \%$ and $17.5 \%$ were $1.4 \times 10^{6}$ cells $/ \mathrm{mL}$ and $1.8 \times 10^{6}$ cells $/ \mathrm{mL}$, respectively. The cell concentrations of $D$. salina cultured in the presence of nitrogen source at a salinity of $12.5 \%$ and $17.5 \%$ was $7.0 \times 10^{5}$ cells $/ \mathrm{mL}$ and $2.4 \times 10^{6}$ cells $/ \mathrm{mL}$, respectively.

The $D$. salina cells in the media were collected by gravity sedimentation under dark conditions between 4 and $50{ }^{\circ} \mathrm{C}$. The statistical significance of differences in cell recovery rates at different temperatures and settlement time was determined by unpaired $t$ test analysis. Results showed statistically significant difference between temperatures $(P<0.05)$ in 13 to $70 \%$ of all tested cases. Normal cells cultured in $17.5 \%$ salinity and settled for $4 \mathrm{~h}$ showed the highest variability in recovery rate between temperatures. Collection by gravity sedimentation was more suitable for the carotenoid-accumulating cells than for normal cells (Fig. 2). The recovery rate of the carotenoid-accumulating cells in the medium with $12.5 \%$ salinity was 89.2 to $99.7 \%$ for $18 \mathrm{~h}$ at any given temperature (Fig. 2a). The recovery rate of the carotenoid-accumulating cells and the normal cells in medium with $12.5 \%$ salinity was higher than that with $17.5 \%$ salinity at each temperature and incubation time (Fig. 2). In particular, the recovery rate of both cells in a short period of time $(4 \mathrm{~h})$ was remarkably different between 12.5 and $17.5 \%$ salinity (Fig. 2). However, the 


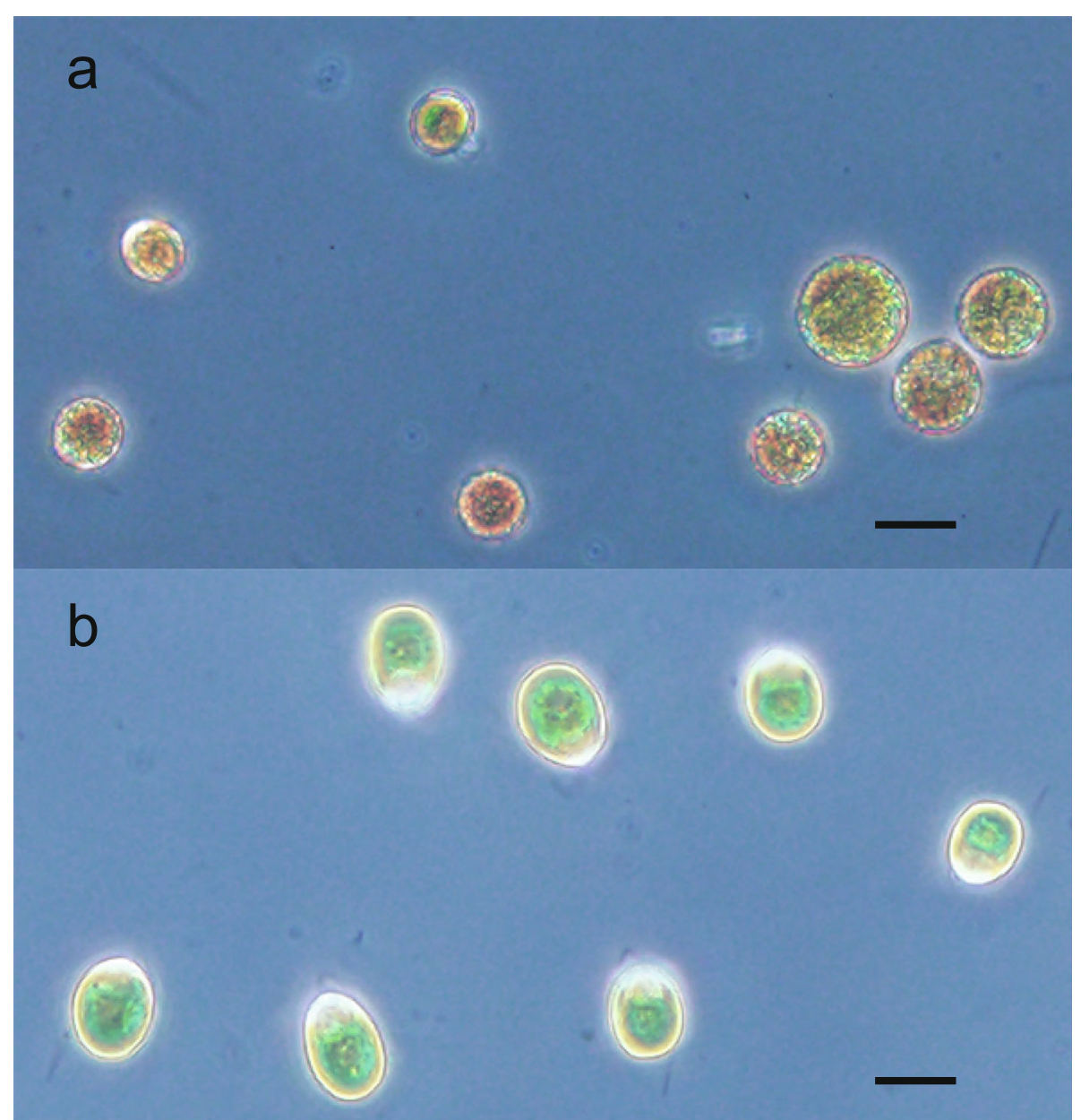

Fig. 1 D. salina cells cultivated under different nutrient conditions. a Cells cultivated in the absence of nitrogen source at 12.5\% salinity. b Cells cultivated in the presence of nitrogen source at $17.5 \%$ salinity. All scale bars indicate $20 \mu \mathrm{m}$

recovery rate of both cells in the media with $12.5 \%$ and $17.5 \%$ salinity was one of the highest at the optimal growth temperature for D. salina (around $25{ }^{\circ} \mathrm{C}$ ) and reached 79.4 to $95.6 \%$ at $20{ }^{\circ} \mathrm{C}, 25{ }^{\circ} \mathrm{C}$, and $30{ }^{\circ} \mathrm{C}$ even after $4 \mathrm{~h}$ (Fig. 2). Additionally, the recovery rates of both cells in the media with $12.5 \%$ and $17.5 \%$ salinity tended to increase at over $40{ }^{\circ} \mathrm{C}$ (Fig. 2). The recovery rate of carotenoid-accumulating cells in both media increased at any given temperature by extending the incubation time; the recovery rate of normal cells in both media increased at temperatures below $20{ }^{\circ} \mathrm{C}$ and at temperatures over $40{ }^{\circ} \mathrm{C}$ by extending the incubation time (Fig. 2).

In this study, the carotenoid-accumulating cells had higher cell recovery rates through gravity sedimentation than the normal cells. The carotenoid-accumulating cells exhibited a marked decrease in motility compared with the normal cells under microscopic observation (data not shown). According to laboratory observations reported by Smayda (1970), phytoplankton sank to the bottom of the flask when they lost their flagella, were stressed to affect their motility, or were senescent (nondividing cells, between maturity and death). Thus, high recovery rates of carotenoid-accumulating cells in gravity sedimentation can be attributed to their low motility. In any case, it is desirable that the carotenoidaccumulating cells with high commercial value are suitable for cell collection by gravity sedimentation. In the gravity sedimentation method, medium volume could be reduced to $10 \%$. This method using gravity is compatible and easy to adapt to scaling-up cell recovery. Thus, recovery of $D$. salina cells by combining gravity sedimentation and centrifugation methods will significantly reduce power consumption when compared with centrifugation alone.

The recovery rates of both cells after $18 \mathrm{~h}$ of incubation increased as the temperature rose above $40{ }^{\circ} \mathrm{C}$ (Fig. 2). Moreover, it was observed under the microscope that 


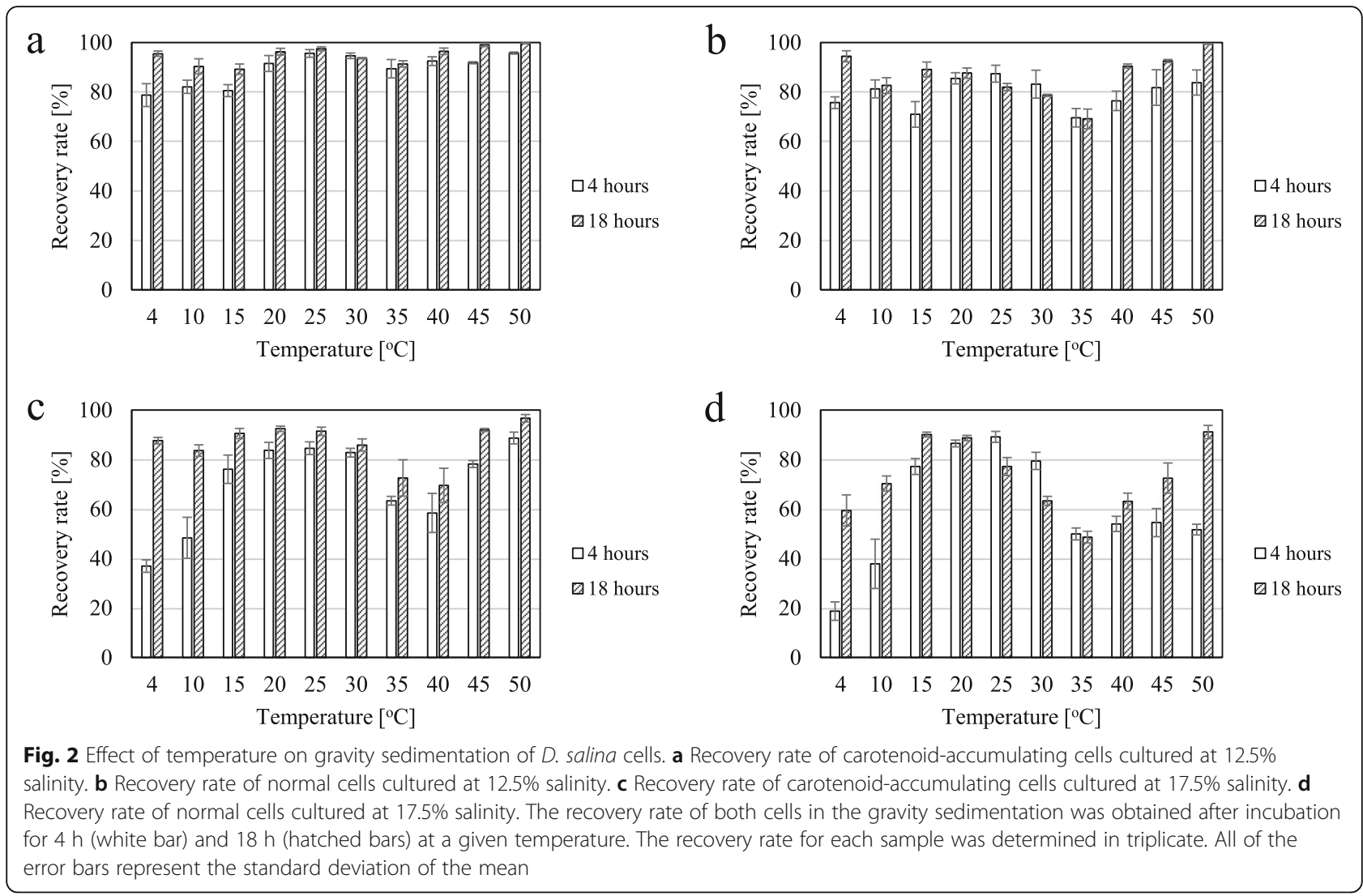

both cells lost motility at over $45{ }^{\circ} \mathrm{C}$ and after $4 \mathrm{~h}$ or more (data not shown). Therefore, it can be said that both cells that lost motility would precipitate-the higher the incubation temperature, the faster they lose motility leading to higher recovery rates of both cells after $18 \mathrm{~h}$. In gravity sedimentation experiments of both cells at $17.5 \%$ salinity medium and $50{ }^{\circ} \mathrm{C}$, it was observed that cells lost motility. Also, the difference in recovery rate of the normal cells after $4 \mathrm{~h}$ and $18 \mathrm{~h}$ was higher than that of the carotenoid-accumulating cells with low motility (Fig. 2c, d). These results also suggested that the motility decrease in $D$. salina cells was effective for precipitation. Except for high incubation temperature cases (above $40{ }^{\circ} \mathrm{C}$ ), the recovery rates with both cells at $12.5 \%$ and $17.5 \%$ salinity media were the highest at $20^{\circ} \mathrm{C}, 25$ ${ }^{\circ} \mathrm{C}$, and $30{ }^{\circ} \mathrm{C}$ (Fig. 2). The optimum growth temperature for $D$. salina is known to be $22{ }^{\circ} \mathrm{C}$ or $25{ }^{\circ} \mathrm{C}$ (Wu et al., 2016). Since the optimum temperature for growth is aligned with the temperature for gravity sedimentation, it can be said that the same temperature is required for both, the cultivation of $D$. salina in open ponds and the gravity sedimentation.

The normal and carotenoid-accumulating cells in the medium with $12.5 \%$ salinity had higher recovery rates than those with $17.5 \%$ salinity at a wide range of temperatures (Fig. 2). These results suggested that D. salina cells in the medium with lower specific gravity precipitate faster. Thus, culture medium with lower salinity is likely suitable for the gravity sedimentation. However, $D$. salina shows optimum growth at about $18-21 \% \mathrm{NaCl}$ (Borowitzka and Borowitzka, 1990). Additionally, it is known that higher salinity ( $>27 \% \mathrm{NaCl})$ in medium is required to result in the maximum $\beta$-carotene accumulation in D. salina and the effective prevention of microbial contamination in outdoor mass cultivation (Borowitzka and Borowitzka, 1990). Therefore, it seems better to perform the gravity sedimentation after lowering the medium salinity by adding seawater or water to the cultured medium, as done in this study. Furthermore, diluting the salt concentration of the medium increases the specific gravity of cultured cells compared with the medium. Thus, we can say that, in this study, motility decrease and relatively high specific gravity of D. salina cells might have led to gravity sedimentation.

The effect of dissolved oxygen on the gravity sedimentation of the carotenoid-accumulating and normal cells cultivated in the media with $12.5 \%$ salinity was investigated. The cell densities of the carotenoid-accumulating and normal cells in the media were $8.2 \times 10^{5}$ cells $/ \mathrm{mL}$ and $7.2 \times 10^{5}$ cells $/ \mathrm{mL}$, respectively. Preparing cellcultured media with different initial oxygen concentrations was achieved by $20 \%$ oxygen or nitrogen purge. 
The incubation temperature in the gravity sedimentation was set to $25^{\circ} \mathrm{C}$ to take economic costs into account.

The recovery rates of both cells under aerobic and anaerobic conditions increased with the sedimentation time (Fig. 3). The significance of differences in cell recovery rates under aerobic and anaerobic conditions at individual time points were determined by an unpaired $t$ test. The differences in the recovery rates of the carotenoid-accumulating cells after $1 \mathrm{~h}$ (Fig. 3a) and the normal cells after $0.5 \mathrm{~h}$ (Fig. $3 \mathrm{~b}$ ) were of borderline significance $(P=0.07$ and 0.09 , respectively), but there were no statistically significant differences at other time points $(P>0.1)$. Therefore, it was indicated that recovery rate of both cells was not significantly affected by the difference of initial dissolved oxygen concentration in the cell-cultured media.

The effect of light and $\mathrm{pH}$ in culture medium on gravity sedimentation of $D$. salina cells was not investigated in this study. However, D. salina has exhibited phototaxis (Wayne et al., 1991) and Dunaliella tertiolecta cells in culture medium has aggregated at $\mathrm{pH}$ between 8.6 and 10.5 (Horiuchi et al., 2003), influenced by some

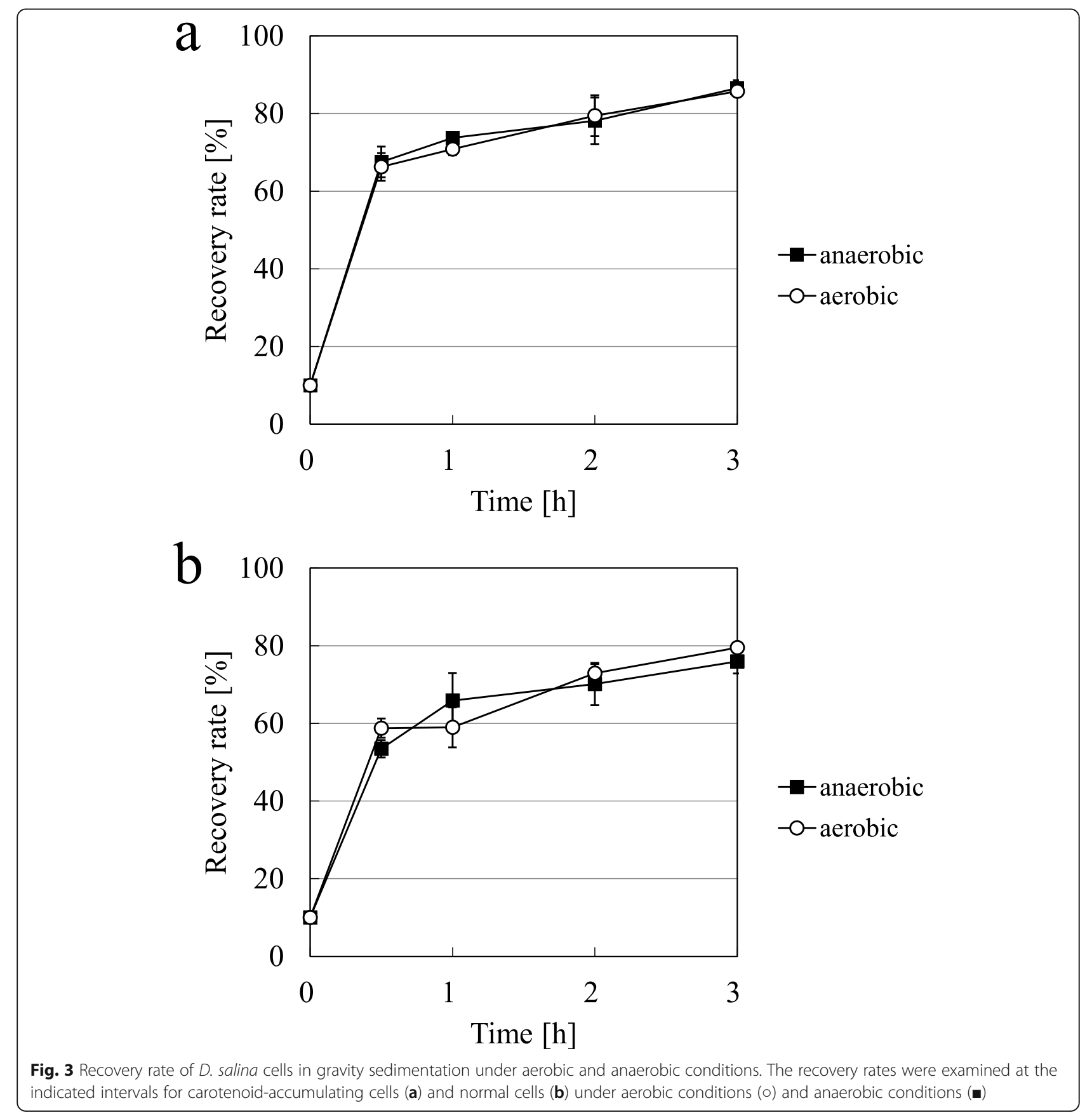


precipitates such as calcium carbonate and magnesium hydroxide induced in culture medium at high $\mathrm{pH}$ (Şirin et al., 2012). Therefore, we must be careful to avoid light and high $\mathrm{pH}(>\mathrm{pH} 8.6)$ in collection of $D$. salina cells by gravity sedimentation.

\section{Conclusions}

D. salina cells were collected by gravity sedimentation in this study. Even though high recovery rates were observed at low and high temperatures in some cases, the gravity sedimentation method ensured high recovery rates of the algal cells at $20{ }^{\circ} \mathrm{C}, 25^{\circ} \mathrm{C}$ and $30{ }^{\circ} \mathrm{C}$ even after $4 \mathrm{~h}$. This temperature range is in good alignment with the optimum temperature range for the microalgal growth. We can say that gravity sedimentation can be readily applied to $D$. salina cultivated in open ponds without cooling or heating systems, probably by transferring it to harvest storage tanks. This technology will be particularly useful to collect Dunaliella salina cells at low cost for subsequent raw material extraction in different industries.

\section{Materials and methods}

\section{Species and culture}

Microalgae Dunaliella salina strain CS-744/01 was used in experiments. The alga was cultivated in liquid $\mathrm{f} / 2$ medium with a salinity of $12.5 \%(2.2 \mathrm{M} \mathrm{NaCl})$ or $17.5 \%$ (3.3 M NaCl) (Guillard and Ryther, 1962). The desired salinity concentrations were reached by adding sea salt (Red Sea Salt used for aquaria), and the $\mathrm{pH}$ of the medium was adjusted to $\mathrm{pH} 8.2$ with $\mathrm{HCl}$. A preculture of $200 \mathrm{~mL}$ was inoculated into $800 \mathrm{~mL}$ of fresh medium in an open tank and incubated at $25^{\circ} \mathrm{C}$ under 10,000 lux of continuous illumination. On the third day, the concentration of $\mathrm{NaNO}_{3}, \mathrm{NaH}_{2} \mathrm{PO}_{4} \cdot 2 \mathrm{H}_{2} \mathrm{O}$, trace elements and vitamin mix were adjusted by adding $1 \mathrm{~mL}$ of stock solution, to reach concentrations specified in the $f / 2$ culture medium. Also, water equivalent to evaporated water were added. The algal cells on the seventh day of cultivation were used for experiments as normal cells. Culture conditions of preculture were the same as those of main culture.

To obtain the algal cells accumulating carotenoids, the alga was cultivated in a medium without a nitrogen source. This was prepared by removing $\mathrm{NaNO}_{3}$ from $\mathrm{f} / 2$ medium with a salinity of $12.5 \%(2.2 \mathrm{M} \mathrm{NaCl})$ or $17.5 \%$ (3.3 M NaCl). The medium's $\mathrm{pH}$ was adjusted to $\mathrm{pH} 8.2$ with $\mathrm{HCl}$. Preculture was prepared as indicated above. Two hundred milliliters of preculture were inoculated into $800 \mathrm{~mL}$ of fresh medium without nitrogen source in an open tank and incubated at $25{ }^{\circ} \mathrm{C}$ under continuous illumination of 10,000 lux. One milliliter of each stock solution removing $\mathrm{NaNO}_{3}$ from $\mathrm{f} / 2$ medium and water equivalent to evaporated water was added to the culture medium on the third day, and the algal cells on the seventh day of cultivation were used for experiments as carotenoid-accumulating cells.

\section{Gravity sedimentation}

The culture media after cultivation were adjusted to $12.5 \%(2.2 \mathrm{M} \mathrm{NaCl})$ or $17.5 \%(3.3 \mathrm{M} \mathrm{NaCl})$ of salinity with water and to $\mathrm{pH} 8.2$ with $\mathrm{NaOH}$ solution. The grown cells in the media were collected by gravity sedimentation. Ten milliliters of the suspended culture media were transferred to $15 \mathrm{~mL}$ conical screw cap tubes (No. 352096; Falcon, Corning), and the tubes were wrapped with aluminum foil for shading. The tubes were stirred on a vortex mixer and incubated at $4{ }^{\circ} \mathrm{C}, 10{ }^{\circ} \mathrm{C}$, $15{ }^{\circ} \mathrm{C}, 20{ }^{\circ} \mathrm{C}, 25{ }^{\circ} \mathrm{C}, 30{ }^{\circ} \mathrm{C}, 35^{\circ} \mathrm{C}, 40{ }^{\circ} \mathrm{C}, 45{ }^{\circ} \mathrm{C}$, and $50{ }^{\circ} \mathrm{C}$ for $4 \mathrm{~h}$ and $18 \mathrm{~h}$. After the incubation, $9 \mathrm{~mL}$ of the supernatant in each tube was transferred to a new tube. Experiments were conducted in triplicate for each temperature and settlement time.

\section{Gravity sedimentation under aerobic and anaerobic conditions}

The salinity of culture media after cultivation was adjusted to $12.5 \%(2.2 \mathrm{M} \mathrm{NaCl})$ or $17.5 \%(3.3 \mathrm{M} \mathrm{NaCl})$ by adding water and to $\mathrm{pH} 8.2$ using $\mathrm{NaOH}$ solution. Ten milliliters of the suspended culture media were transferred to $15 \mathrm{~mL}$ conical screw cap tubes. The culture medium in the tubes was purged with $20 \%$ oxygen and $80 \%$ nitrogen or $100 \%$ nitrogen for 10 min prior to the gravity sedimentation experiment, with the tubes wrapped with aluminum foil. The tubes were stirred on a vortex mixer and incubated at $25^{\circ} \mathrm{C}$ for $0.5 \mathrm{~h}, 1 \mathrm{~h}, 2 \mathrm{~h}$, and $3 \mathrm{~h}$. After the incubation, $9 \mathrm{~mL}$ of the supernatant in each tube was transferred to a new tube. Experiments were conducted in triplicate for each tested case.

\section{Observation and cell count}

The cultured cells were observed under a phase-contrast Olympus BX53 microscope equipped to a CCD camera system. The number of the algal cells in the culture media and supernatants were counted using an improved Neubauer chamber and the microscope.

\footnotetext{
Acknowledgements

This work was supported in part by the Grant-in-Aid for Scientific Research granted by the Japanese Ministry of Education, Culture, Sports, Science and Technology (MEXT KAKENHI Grant Number 15K12262). We would like to express our deep appreciation to Dr. Ken Takai and Dr. Hiroyuki Yamamoto from the Japan Agency for Marine-Earth Science and Technology for providing the necessary resources, equipment, and facilities to conduct this research. The authors would also like to thank Mitsubishi Gas Chemical Company, Inc. for their support in the research fund.
}

Authors' contributions

TW conceived the original idea, carried out experiments, analyzed the data, and wrote the manuscript. AN contributed to the analysis of the results and to the writing of the manuscript. YM performed experiments. MK obtained 
research fund and supervised the overall project. All authors discussed the results, read, commented, and approved the final manuscript.

\section{Funding}

Grant-in-Aid for Scientific Research granted by the Japanese Ministry of Education, Culture, Sports, Science and Technology (MEXT KAKENHI Grant Number 15K12262).

\section{Availability of data and materials}

All data generated or analyzed during this study are included in this published article.

\section{Declarations}

Ethics approval and consent to participate

Not applicable.

\section{Consent for publication}

Not applicable.

\section{Competing interests}

The authors declare that they have no competing interests.

\section{Author details}

${ }^{1}$ Graduate School of Agricultural and Life Sciences, The University of Tokyo, 1-1-1 Yayoi, Tokyo, Bunkyo-ku 113-0032, Japan. ²Department of Food and Nutrition, Higashi Chikushi Junior College, 5-1-1 Shimoitozu, Kokurakita-ku, Fukuoka, Kitakyushu 803-0846, Japan.

\section{Received: 11 March 2021 Accepted: 15 June 2021}

\section{Published online: 09 July 2021}

\section{References}

Ariede MB, Candido TM, Jacome ALM, Velasco MVR, de Carvalho JCM, Baby AR (2017) Cosmetic attributes of algae-a review. Algal Res 25:483-487. https:// doi.org/10.1016/j.algal.2017.05.019

Ben-Amotz A (1995) New mode of Dunaliella biotechnology: two-phase growth for $\beta$-carotene production. J Appl Phycol 7(1):65-68. https://doi.org/10.1007/ BF00003552

Ben-Amotz A, Tornabene TG, Thomas WH (1985) Chemical profile of selected species of microalgae with emphasis on lipids. J Phycol 21(1):72-81

Borowitzka LJ, Borowitzka MA (1990) Commercial production of $\beta$-carotene by Dunaliella salina in open ponds. Bull Mar Sci 47(1):244-252

Borowitzka M (1999) Commercial production of microalgae: ponds, tanks, and fermenters. Prog Ind Microbiol 35:313-321. https://doi.org/10.1016/S0079-63 52(99)80123-4

Borowitzka MA (1997) Microalgae for aquaculture: opportunities and constraints. J Appl Phycol 9(5):393-401. https://doi.org/10.1023/A:1007921728300

Chatsungnoen T, Chisti Y (2016) Harvesting microalgae by flocculationsedimentation. Algal Res 13:271-283. https://doi.org/10.1016/.algal.2015.12.009

Chew KW, Yap JY, Show PL, Suan NH, Juan JC, Ling TC, Lee D-J, Chang J-S (2017) Microalgae biorefinery: high value products perspectives. Bioresour Technol 229:53-62. https://doi.org/10.1016/j.biortech.2017.01.006

Chisti Y (2018) Society and microalgae: understanding the past and present, microalgae in health and disease prevention. Elsevier, pp 11-21

Coesel S, Baumgartner A, Teles L, Ramos A, Henriques N, Cancela L, Varela (2008a) Nutrient limitation is the main regulatory factor for carotenoid accumulation and for Psy and Pds steady state transcript levels in Dunaliella salina (Chlorophyta) exposed to high light and salt stress. Mar Biotechnol 10(5):602-611. https://doi.org/10.1007/s10126-008-9100-2

Elloumi J, Carrias J-F, Ayadi H, Sime-Ngando T, Bouaïn A (2009) Communities structure of the planktonic halophiles in the solar saltern of Sfax, Tunisia. Estuar Coast Shelf Sci 81(1):19-26. https://doi.org/10.1016/j.ecss.2008.09.019

Eppley RW, Holmes RW, Strickland JD (1967) Sinking rates of marine phytoplankton measured with a fluorometer. J Exp Mar Biol Ecol 1(2):191208. https://doi.org/10.1016/0022-0981(67)90014-7

Fisher M, Pick U, Zamir A (1994) A salt-induced 60-kilodalton plasma membrane protein plays a potential role in the extreme halotolerance of the alga Dunaliella. Plant Physiol 106(4):1359-1365. https://doi.org/10.1104/pp.106.4.1359

Grima EM, Belarbi E-H, Fernández FA, Medina AR, Chisti Y (2003) Recovery of microalgal biomass and metabolites: process options and economics.
Biotechnol Adv 20(7-8):491-515. https://doi.org/10.1016/S0734-9750(02 )00050-2

Guillard RR, Ryther JH (1962) Studies of marine planktonic diatoms: I. Cyclotella nana Hustedt, and Detonula confervacea (Cleve) gran. Can J Microbiol 8(2): 229-239. https://doi.org/10.1139/m62-029

Horiuchi J-I, Ohba I, Tada K, Kobayashi M, Kanno T, Kishimoto M (2003) Effective cell harvesting of the halotolerant microalga Dunaliella tertiolecta with $\mathrm{pH}$ control. J Biosci Bioeng 95(4):412-415. https://doi.org/10.1016/S1389-1723(03)80078-6

Li S, Hu T, Xu Y, Wang J, Chu R, Yin Z, Mo F, Zhu L (2020) A review on flocculation as an efficient method to harvest energy microalgae: mechanisms, performances, influencing factors and perspectives. Renew Sust Energ Rev 131:110005

Mata TM, Martins AA, Caetano NS (2010) Microalgae for biodiesel production and other applications: a review. Renew Sust Energ Rev 14(1):217-232. https://doi. org/10.1016/j.rser.2009.07.020

Milledge JJ (2011) Commercial application of microalgae other than as biofuels: a brief review. Rev Environ Sci Biotechnol 10(1):31-41. https://doi.org/10.1007/ s11157-010-9214-7

Milledge JJ, Heaven S (2013) A review of the harvesting of micro-algae for biofuel production. Rev Environ Sci Biotechnol 12(2):165-178. https://doi. org/10.1007/s11157-012-9301-z

Morais WG Jr, Gorgich M, Corrêa PS, Martins AA, Mata TM, Caetano NS (2020) Microalgae for biotechnological applications: cultivation, harvesting and biomass processing. Aquaculture 735562. https://doi.org/10.1016/j.aqua culture.2020.735562

Najiar YS, Abu-Shamleh A (2020) Harvesting of microalgae by centrifugation for biodiesel production: a review. Algal Res 51:102046. https://doi.org/10.1016/ j.algal.2020.102046

Okoro V, Azimov U, Munoz J, Hernandez HH, Phan AN (2019) Microalgae cultivation and harvesting: growth performance and use of flocculants-a review. Renew Sust Energ Rev 115:109364. https://doi.org/10.1016/.rser.2019.109364

Post F, Borowitzka L, Borowitzka M, Mackay B, Moulton T (1983) The protozoa of a Western Australian hypersaline lagoon. Hydrobiologia 105(1):95-113. https://doi.org/10.1007/BF00025180

Pourkarimi S, Hallajisani A, Alizadehdakhel A, Golzary A (2020) Factors affecting production of beta-carotene from Dunaliella salina microalgae. Biocatal Agric Biotechnol 101771

Ramos AA, Polle J, Tran D, Cushman JC, Jin E-S, Varela JC (2011) The unicellular green alga Dunaliella salina Teod. As a model for abiotic stress tolerance: genetic advances and future perspectives. Algae 26(1):3-20. https://doi.org/1 0.4490/algae.2011.26.1.003

Şirin S, Trobajo R, Ibanez C, Salvadó J (2012) Harvesting the microalgae Phaeodactylum tricornutum with polyaluminum chloride, aluminium sulphate, chitosan and alkalinity-induced flocculation. J Appl Phycol 24(5): 1067-1080. https://doi.org/10.1007/s10811-011-9736-6

Smayda TJ (1970) The suspension and sinking of phytoplankton in the sea. Oceanogr Mar Biol Annu Rev 8:353-414

Spolaore P, Joannis-Cassan C, Duran E, Isambert A (2006) Commercial applications of microalgae. J Biosci Bioeng 101(2):87-96. https://doi.org/10.1263/jbb.101.87

Uduman N, Qi Y, Danquah MK, Forde GM, Hoadley A (2010) Dewatering of microalgal cultures: a major bottleneck to algae-based fuels. J Renewable Sustainable Energy 2(1):012701. https://doi.org/10.1063/1.3294480

Velan M, Saravanane R (2013) Pollution abatement and utilization of flue gas for bioenergy production - a review. Intl J Emerg Technol Advanced Eng 3:94-99

Verma NM, Mehrotra S, Shukla A, Mishra BN (2010) Prospective of biodiesel production utilizing microalgae as the cell factories: a comprehensive discussion. Afr J Biotechnol 9(10):1402-1411

Wayne R, Kadota A, Watanabe M, Furuya M (1991) Photomovement in Dunaliella salina: fluence rate-response curves and action spectra. Planta 184(4):515524. https://doi.org/10.1007/BF00197901

Wu Z, Duangmanee P, Zhao P, Juntawong N, Ma C (2016) The effects of light, temperature, and nutrition on growth and pigment accumulation of three Dunaliella salina strains isolated from saline soil. Jundishapur J Microb 9(1): e26732. https://doi.org/10.5812/jjm.26732

Yen H-W, Hu I-C, Chen C-Y, Ho S-H, Lee D-J, Chang J-S (2013) Microalgae-based biorefinery-from biofuels to natural products. Bioresour Technol 135:166174. https://doi.org/10.1016/j.biortech.2012.10.099

\section{Publisher's Note}

Springer Nature remains neutral with regard to jurisdictional claims in published maps and institutional affiliations. 